IP Periodica Polytechnica

Social and Management

Sciences

25(2), pp. 79-86, 2017

https://doi.org/10.3311/PPso.9796

Creative Commons Attribution (i)

RESEARCH ARTICLE

\section{Bioenergy in the Republic of}

Macedonia: Regulatory Uncertainties,

EU Policies, and Civil Society

Opinions Shape the Narrative

\author{
Prithvi Simha ${ }^{1,2^{*}}$, Krithi Venkat ${ }^{1,3}$
}

Received 24 July 2016; accepted after revision 15 September 2016

\begin{abstract}
The continued expansion in the use of bioenergy is vital if the EU is to achieve its targets for renewable energy in 2020 and 2030. Several Central and Eastern European Countries (CEECS) are candidates for accession to the EU and this potential enlargement of the Union could extend the production of bioenergy to this region. This research explores the impacts of policies, regulatory frameworks, legislative environment and the role of civil society organizations in shaping the biofuel investment climate in CEECs. Specifically, we bring to light aspects that could hinder the potential introduction and development of bioenergy in the CEECs by using the Republic of Macedonia as the case study. We find the predominant resisting factors to bioenergy projects in the CEECs to be-legislative vacillations, regulatory reservations in EU policies, uncertainties in biofuel targets for the post-2020 phase and aggressive lobbying by the civil society on grounds of sustainability of biofuels. We believe that, for advanced biofuel projects to succeed in the CEECs, the challenge does not lie in commercialization of an unproven, new-to-market technology; the real test will be to see if relevant stakeholders can shape the narratives adopted by the EU for its post-2020 phase of the Renewable Energy Directive and ensure that the Government of Macedonia complies with its provisions.
\end{abstract}

\section{Keywords}

biofuels, Renewable Energy Directive, Energy Community, Central and Eastern European countries, investment climate

\footnotetext{
${ }^{1}$ Department of Environmental Sciences and Policy, Central European University, Nádor u. 9, 1051 Budapest, Hungary

${ }^{2}$ School of Earth, Atmospheric and Environmental Sciences (SEAES), The University of Manchester, Oxford Road, Manchester, M13 9PL, United Kingdom

${ }^{3}$ International Institute for Industrial Environmental Economics (IIIEE), Lund University, Box 117, 22100 Lund, Sweden

*Corresponding author, e-mail: prithvi.simha@mespom.eu
}

\section{Introduction}

Bioenergy or energy from biomass resources such as agricultural residues, wood, and energy crops has been advocated as a sustainable, renewable and cleaner approach for ensuring security of energy supply (Bauen et al., 2009). Bioenergy has certainly found favour and been perceived as a good substitute to the use of fossil fuels for primary energy production in the European Union (EU). This is evident in the share of biomass resources in the growing renewable energy mix of the EU; in 2014, solid biofuels and waste biomass accounted for $63.1 \%$ of the total primary renewable energy produced in the EU-28 (Faaij, 2006; Eurostat, 2016). A continued expansion in the use of biomass is central to the EU's 2020 vision wherein renewable energy is to account for $20 \%$ of the final energy consumption and $10 \%$ of the energy mix in transportation (Scarlat et al., 2015).

However, as van Dam et al. (2007) note, since the EU already utilises and recycles waste and residues to a high degree any expansion of bioenergy will likely have to come by increasing the production of energy crops. With most productive arable land already cultivated, the cultivation of energy crops in the EU-28 would require displacement of farms that grow food crops or forest area, both of which would result in socio-environmental externalities. Several Central and Eastern European Countries (CEECs) are candidates for accession to the EU and this potential enlargement of the Union adds a new dimension to the EU renewable energy and bioenergy scene. Large tracts of abandoned farms (52.5 Mha; Alcantara et al., 2013), low agro-productivity vis-à-vis that in western Europe, high share of population in the agricultural sector, comparatively lower cost of crop production and bioenergy production (Lewandowski et al., 2006), etc. are few aspects that have prompted the recent discussions on the feasibility of extending biomass production to the CEECs.

In the EU, investment in the energy sector and markets in is governed and regulated by legally binding EU-level directives and respective national legislations. Furthermore, the Energy Community, a treaty agreed in 2005 between the EU and several EU-candidacy seeking CEECs, strives to establish a process to streamline the integration of the CEECs by adoption of 
EU legislations on energy. The Republic of Macedonia (or The Former Yugoslav Republic of Macedonia) has been a longstanding candidate for EU membership and is a Contracting Party to the Energy Community Treaty. This obligates the country to implement relevant EU energy acquis communautaire, the central aim being to establish a pan-European energy market and extend the EU energy acquis.

With respect to bioenergy, the EU biofuel policy has been met with strong opposition from the civil society on grounds of the 'food versus fuel' debate (Balat and Balat, 2009). Additionally, concerns surrounding the impacts of biofuel production on indirect land use change (ILUC), i.e. increase in the net greenhouse gas emissions in the life cycle of biofuels remain unresolved (Fargione et al., 2008). The argument that has been put forth is that, the EU biofuel policy promotes and subsidizes the use of arable land for the production of fuel rather than using it for the production of food (De Schutter, 2014). On the contrary, several studies have emphasized the potential of CEECs to contribute to EU renewable energy targets by expanding their national bioenergy production levels (See Fischer et al., 2005; Kondili and Kaldellis, 2007; van Dam et al., 2007; Alcantara et al., 2013; De Lucia and Bartlett, 2014)

Therefore, it is the aim of the present study to gauge the impacts of the relevant EU and Macedonian laws, regulatory frameworks, policies, and investment climate in order to bring to light any gaps in compliance that hinder the potential introduction and proliferation of bioenergy production in the CEECs by using the Republic of Macedonia as the case study. This study also ventures into the perceptions and opinions of civil society organizations (both in the EU and in Macedonia) on cellulosic ethanol projects in order to elucidate how they influence the investment climate for second generation biofuel production in the region.

\section{Regulatory Uncertainties in EU Policies}

As part of its Climate and Energy package, the EU Renewable Energy Directive (RED) $\{2009 / 28 / E C\}$ is Europe's central policy instrument for renewable energy proliferation (EU, 2009). The RED provides an overarching framework for Member States to collectively increase their share of RE production to $20 \%$ of their consumption by 2020 (See Fig. 1). Recently, the European Council agreed to extend this vision to 2030 where the commitment will be for an 'at least $27 \%$ ' share of renewable energy, 'at least $27 \%$ ' improvement in energy efficiency as well as a $40 \%$ reduction in greenhouse gases as against 1990 levels (Knopf et al., 2015). This agreement comes on the backdrop of sustained increase in the EU-wide renewable energy production which already accounted for $\sim 16 \%$ of the gross energy consumption in 2014; as per its 2015 interim renewable energy progress report, 25 of the EU-28 countries are comfortably poised to meet their 2020 targets (EC, 2015). Furthermore, the target of $27 \%$ share of renewables in the energy mix has been set by the Commission based on its own energy modelling which indicates that, to attain a $40 \%$ reduction in greenhouse gas emissions (vis-à-vis 1990 levels), a cost-effective solution would be to expand renewable energy production to result in $26.5 \%$ share in final energy consumption by 2030 (Knopf et al., 2015). This is in line with the Commission's ambitious longterm vision of a low-carbon economy across the EU in 2050 where there would be $80-95 \%$ decrease in greenhouse gases and hence, would require $55-75 \%$ contribution of renewables in energy production (Scarlat et al., 2015).

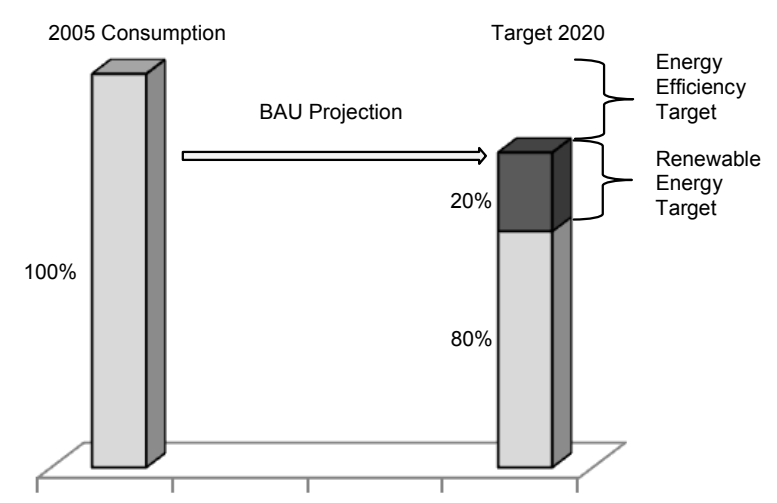

Fig. 1 Gross final energy consumption in the EU and targets for 2020

The EU began the process of creating a liberalized internal energy market in the 1990s to allow demand-supply equilibrium to establish low end-user prices (EU, 1996). Subsequently, over the years the number of private entities in the European energy market has grown by over 18\% (EMCC, 2008). However, as Levi-Faur (2009) points out, liberalization has also ushered in regulatory capitalism as a means of reasserting state authority; most national energy markets in the EU still remain highly regulated. Despite these measures, even today the EU's energy security hinges substantially on foreign imports of natural gas and LNG; primarily, this involves imports from Russia (39\%), Norway (34\%) and Algeria (13\%) and Qatar (7\%) (Ruble, 2015). Increasing its share of renewable energy through the implementation of RED coupled with an internally regulated market is perceived by the EU to be vital in securing its long-term energy supply security. To this effect, the RED leaves the choice of energy technologies for Member States to decide through the adoption and implementation of individually tailored National Renewable Energy Action Plans (NREAPs) (Atanasiu, 2010). Besides, Annex I in the RED specifies the level of effort differentiated across MS with a sub-target mandating use of $10 \%$ renewable energy in transportation fuels (blending) in every Member State.

Articles 16-18 of the RED are concerned with biofuel/ bioliquids production and use. They set the sustainability criteria and compliance norms that guide Member States on adoption of various feedstocks and processing technologies. As part of its obligation under Article 17(9), the EC published 
a comprehensive report on the sustainability criteria requirements for biomass-based energy production (EC, 2010). However, citing the wide array of feedstock available as a constraint, the EC did not put forward a harmonized scheme nor did it propose any binding criteria for MS at the EU level.

The initial goal proposed by the EU biofuels directive was to achieve a blend target of $5.75 \%$ ethanol in transportation fuel by 2010 which was further increased to $10 \%$ by the RED as a part of the 2020 climate and energy strategy. Alongside the RED, the Fuel Quality Directive mandated a $6 \%$ reduction of greenhouse gases produced by transport and non-transport fuel which was supported by EU subsidies ( $€ 8.4$ billion) for the production of biofuels (IISD, 2013).

However, in the past few years the EU biofuels policy has been under heavy criticism from both the academia and civil society for failure to take into consideration Indirect Land Use Change (ILUC)-related greenhouse gas emissions. This error was acknowledged through a study commissioned by the EU Parliament which recognizes a 'potential' significant impact arising from ILUC during bioenergy feedstock production (EC, 2011). However, these studies have been inconclusive given the complexities associated with ILUC modelling (Laborde 2011; Edwards et al. 2010). Since these findings the EC has adopted a more 'precautionary' approach towards biofuels. This is reflected in its amended position on biofuels (December 2014) where the share of conventional biofuels in transportation has dropped to $7 \%$ and those of advanced-biofuels to $0.5 \%$ points.

Conversely, the biofuels industry has argued that, given the ambiguity and poor reliability of the modelling ILUCs should not be factored into the GHG emissions accounting (Di Lucia et al., 2012). The industry would like to see low or no-ILUC risk biofuels allocated to the RE share, free of the proposed $7 \%$ transportation fuels ceiling as a means to allow further market penetration of best performing biofuels (ePURE, 2014). Nonetheless, the single largest impediment to increased biofuel integration into the energy mix has been the uncertainties in the RED and EU energy policies for the post-2020 phase. Within a span of 5 years the industry has already witnessed the EU backtrack from its earlier $10 \%$ blend target to $7 \%$. As things stand today, even the sub-target of $0.5 \%$ for advanced biofuels would entail an estimated $€ 3$ billion initial investment. Such an outlay could only be justified to investors if post-2020 targets are known, disclosed, and increase progressively over the years. Unsurprisingly, regulatory uncertainty beyond 2020 has even lead to the closure of one of the five advanced biofuels projects in the EU on grounds of failure to reach purchasing agreements with end-users (See Vapo, 2014). Such legislative obscurities especially for the post-2020 phase where the production from new plants is likely to undergo market realization and seek potential end-users has translated into investor skepticism and driven down the market confidence for advanced biofuels.

\section{Perception Study}

Over the years, governmental support for the promotion and use of biofuels has been criticized extensively by the civil society, claims later substantiated by academic studies on the grounds of land grabbing, low energy return ratio, resource intensiveness in its production and predominantly, the food versus fuel debate (Action Aid, 2012; Eide, 2008; Oxfam International, 2008; FIAN, 2008; Matondi et al., 2011; Schulze, 2012). Alternatively, second generation or non-food based biofuels have brought up concerns on the changes in ecosystem services their use can initiate. For instance, the removal of agricultural residues and forestry waste (say, wood chips) used for advanced biofuel production affect natural material cycles, impact carbon capture and storage capacity and water requirement of soil (Gul et al., 2014). They have low energy return on investment which is seen to vary from a ratio of $1: 1$ to $11: 1$ for conventional and advanced biofuels, respectively by considering the use of biofuel as the energy source in the production unit; this is in stark contrast when compared to a ratio of $20: 1$ for fossil fuels thus rendering biofuels to be dependant on external financial support (subsidies) to ensure market competitiveness (Solomon, 2010; Hammerschlag, 2006).

Further, biofuel projects irrespective of whether they produce conventional or advanced biofuels have received extensive pushback from civil society in the EU and specifically in the CEECs (ActionAid et al., 2013; ActionAid et al., 2015). Among other NGOs, Transport and Environment (TE), BirdLife International (BL) and the European Environmental Bureau (EEB) have put forth strong views on the EC's policy, lobbying for further reduction on the cap to $5 \%$ for production of land-based ethanol, to use ILUC as sustainability criteria for both RED and Fuel Quality Directive and to incentivise advanced biofuel projects with proper carbon accounting (TE, BL and EEB, 2014). In view of such strong arguments and flippant changes in EU policies on biofuels, investor skepticism for biofuel projects has risen. To further elucidate the roadblocks in investment of advanced biofuels, the following section explores the perception among civil society actors in the EU and specifically in Macedonia on possible post-2020 biofuel policy.

\subsection{Civil society perception}

A review of civil society opinions of biofuels revealed that, there is very little literature that specifically captures the opinion of organizations and groups on the impacts of production of second generation biofuels in Macedonia and the CEECs. Organizations in the region however do support the ongoing debate at the EU level on food versus fuel and advocate for the inclusion of ILUC into the sustainability criteria and a slow phasing out of the use of biofuels in the EU (Actionaid et al., 2013).

In a public consultation document on the regional energy strategy of the energy community, retrieved from the Energy 
Community webpage (EC, 2012b), Ms Ana Colovic Lesoska of CEE Bankwatch Network, and also the vice president of Eko Svest, Macedonia discusses her opinions on the challenges to sustainable energy production, renewable energy investment climate of Macedonia, the investment barriers and the possible way around it to improve necessary investments in the country. On the topic of biofuels and biomass for energy production, she explicitly states the need for the inclusion of ILUC in the determination of sustainability of the project and selection of energy technologies accounting for the GHG emissions, water and other resource intensiveness alongside the capacity of the location selected for energy production. She also emphasises on the use of locally sourced resources and the production of energy on a local and small scale through biomass. She also mentions the importance of subsidising renewable energy technologies and low cost grants, loans for investment into Energy Service Companies (ESCOs) (EC, 2012b). Eko Svest, as a part of CEE Bankwatch also advocate for the careful setting of biofuel-use targets due to integrated impact train that these targets would set off in the realm of biodiversity loss, soil degradation, resource intensiveness, food prices, land prices and employment among others (CEE Bankwatch Network, 2010).

Despite these opinions among civil society players, it can be seen from the renewable energy note given by the Energy Agency of the Republic of Macedonia that the country targets to move away from conventional gasoline and diesel to using biofuels with a target of achieving $10 \%$ use by 2020 . They however also mention, almost immediately, the need for continued development in second generation biofuel production and the presence of agricultural waste, $30 \%$ of the total available for biofuel production. (Energy Agency of the Republic of Macedonia, 2015)

In terms of the post-2020 policy, more in-depth scientific analysis on the impacts of biofuels and entire lifecycle of production of biofuels are now being specifically considered by the EU through an online consultation with stakeholders (EC, 2016). Biofuels may not be promoted at the macro scale, but may find favour at a smaller scale and as a transition fuel while investment in the development of cleaner and more efficient renewable energy technologies continues.

\section{The Macedonian Legislative Environment}

Lignite is the primary source of energy production in Macedonia. With no domestic oil or gas reserves, the country is highly dependent on energy imports which account for $48.4 \%$ of its final energy use in 2013 (World Bank, 2016). The primary legislation governing renewable energy is the Macedonian Law on Energy (2006) which, while not setting any concrete targets for share of renewable energy in the energy mix, encourages its use. The legislation also includes provisions for construction and/or licensing of new energy facilities. Currently, a new Energy Law is being drafted to specify and extend the mandate of its Energy Regulatory Commission and progressively adopt
EU standards (Markovska et al., 2009). Since it also operates Guarantees of Origin ( $\mathrm{GoO})$, Macedonia provides preferential treatment to renewable energy suppliers including the obligation for the market operator Elektrani na Makedonija (ELEM) to buy all energy produced by such entities. However, the country has failed to adopt or submit its NREAP to the Energy Community (Georgiev, 2015). Though a number of primary and secondary legislations are in place that provide institutional framework for renewable energy promotion in the country, a policy-gap analysis was conducted to indicate its degree of compliance with the RED and is summarized in Table 1.

In 2012, Macedonia decided to adopt the RED of 2009 into their Energy law and agreed to a target of 28\% share of renewable energy by the year 2020 (Energy Community, 2012a). The country however has not been able to translate these goals into their new law. As per the law and the renewable energy action plan produced in 2015 , the country targets a $28 \%$ renewable energy share by 2030 and only $21 \%$ by 2020 (Government of Republic of Macedonia Ministry of Economy, 2015; Energy Community, 2016).

The renewable energy strategy published by the government details specific measures that could assist compliance against the RED to a large extent (Government of Republic of Macedonia Ministry of Economy, 2015; Energy Community, 2016). However, analysis by the Energy Community has revealed that inefficiencies still exist in terms of unclear mechanisms of coordination between authorities. Additionally, rules for authorization, licencing, certification, transmission and distribution with respect to renewable energy connection to the grid have been found to be either unclear or not transposed. There is no mention of any provisions related to co-operation mechanisms among the Member States or contracting parties. Moreover, there is no mention of the sustainability criteria for biofuels in the transport sector, making it widely inconsistent with the RED (Energy Community, 2016). Nonetheless, as of 2014, Macedonia had already achieved a $22 \%$ renewable energy penetration with provisions of its draft NREAP expressing intent to install an additional $50 \mathrm{GWh}$ of biomass-based energy by 2020 (EU, 2016). However, in order to cement its candidature for EU membership, Macedonia must fulfil its RED commitments by first adopting its draft NREAP and setting sectoral energy targets; this would in turn determine the amount of ethanol power generated by a biomass-based energy project that must be preferentially procured by ELEM. Moreover, the Energy Law must explicitly define 'bioliquids' and the sustainability criteria for bioenergy production including the initial feedstock (Woody crops, agricultural residues, waste etc.).

The most significant obstacle however is the lack of provision in the law for implementation of 'Joint Projects' (with third parties) or 'Statistical Transfers' (excess energy from any biofuel project in the country will be exported to the EU market). In addition, $\sim 58 \mathrm{GWh}$ of project electricity will be sent to the 
Table 1 Macedonian legislative compliance with the EU RED (IPA 2010; IEA 2008; Ćosić et al., 2012; Dedinec et al., 2013; Markovska et al., 2009; Government of Republic of Macedonia Ministry of Economy, 2015; Energy Community, 2016)

\begin{tabular}{lll}
\hline RED Directive 2009/28/EC & Current Provisions in Macedonian Legislation & Compliance \\
\hline Article 2 - Definitions & & \\
(a) Energy from Renewable non-fossil sources & Energy Law 2006, Article 8.87: & $Y$ \\
& RE resources shall mean renewable non-fossil energy sources \\
(g) District heating or cooling & $\begin{array}{l}\text { Energy Law 2006 Article 8.65/72: Thermal energy is generated } \\
\text { energy intended for heating facilities }\end{array}$ & $Y$ \\
(h) Bioliquids & No definition & $N$ \\
(i) Biofuels & Energy Law 2006 Article 8.88; Biofuels shall mean liquid/gaseous & $Y$ \\
& fuel for transport produced from biomass & $Y$ \\
(j) Guarantee of origin (GoO) & Energy Law 2006 Article 8.85 GoO is issued by EARM certifying & $Y$ \\
& electricity is produced from RES & $N$ \\
(k) Support schemes & No definition & \\
\hline
\end{tabular}

\section{Article 3 - Mandatory National Targets and Measures}

National RE targets to be met by 2020; consistent with $20 \%$

Energy strategy states a $21 \%$ target renewable energy share by

$N$

Community target, calculated as a share of gross final energy 2020 and $28 \%$ by 2030 . This however is not in compliance with consumption; General national biofuels target of $10 \%$ of final energy consumption in transport to bet met by 2020 .

the agreed targets as of 2012 .

Measures shall be introduced to promote RE and Biofuels

Feed-in tariffs currently provided with associated rule books for

biomass and biogas plants. Provision for further support schemes

is envisaged by the Energy Law Article 139.

\section{Article 4 - National Renewable Energy Action Plans}

Action plans must be submitted annually

First annual Renewable Energy action plan published in November $Y$ 2015; No annual action plans outlined

Overview of all policies concerning RES

Overview is given

Yes in draft

Specific measures to fulfil Articles 13, 14, 16, and 17 to 21

Specific measures for administration, information and training

Partial

have been presented, however they require revisions

Information on sustainability of biofuels and bioliquids is absent

Specific measures for biomass

Specific measures for increasing utilization of biomass are given Yes in draft

No planned use of statistical transfers/participation in joint projects $N$

Planned use of statistical transfers between MS and planned

participation in joint projects

\section{Article 7 to 10 - Joint projects}

MS can engage with other MS or third parties in joint projects for No provisions made for joint projects

target compliance purposes (Art. 7 and 9)

\begin{tabular}{|c|c|c|}
\hline Article 11 - Joint Support schemes & No provisions for joint support schemes & $N$ \\
\hline Article 14 - Information and Training & $\begin{array}{l}\text { No specific training programs are mentioned; need for public } \\
\text { awareness schemes is outlined in the Energy Law (Article 139) }\end{array}$ & $N$ \\
\hline Article 16 - Access to and operation of Grids & $\begin{array}{l}\text { Distribution Grid Code has been amended to make provisions } \\
\text { for renewables; however revisions rules for transmission and } \\
\text { distribution have not been entirely transposed }\end{array}$ & Partial \\
\hline $\begin{array}{l}\text { Transmission and distribution of electricity from RE shall be } \\
\text { guaranteed by T/DSOs in their territories }\end{array}$ & $\begin{array}{l}\text { Energy Law Article } 141 \text { requires Market operators to purchase all } \\
\text { electricity generated from RE }\end{array}$ & Y \\
\hline Priority or guaranteed access for RE shall be provided by MS & $\begin{array}{l}\text { Energy Law Article } 8.86 \text { designates RE producers as preferential } \\
\text { producers of electricity }\end{array}$ & Y \\
\hline $\begin{array}{l}\text { T/DSOs have to make public standard rules on costs for technical } \\
\text { adaptation and these rules shall be nonbiased and based on all } \\
\text { costs and benefits of connection of new producers }\end{array}$ & No provision made & $N$ \\
\hline Article 17 - Sustainability criteria for Biofuels \& Bioliquids & $\begin{array}{l}\text { Draft Energy Strategy sets targets for } 2020 \text { to reduce gross GHG } \\
\text { emissions by } 30 \% \text { \& in electricity sector by } 20 \%\end{array}$ & Partial \\
\hline $\begin{array}{l}\text { They shall not be made from raw materials from certain land types } \\
\text { (high biodiversity, designated areas, biodiverse grassland, land } \\
\text { with high carbon stock, peatland) }\end{array}$ & $\begin{array}{l}\text { Draft Energy Strategy envisages production of biomass and animal } \\
\text { fat for conversion to biofuels. No other discussion of source of raw } \\
\text { materials }\end{array}$ & $N$ \\
\hline $\begin{array}{l}\text { Agricultural raw materials needs to be in accordance with com- } \\
\text { mon agricultural policy }\end{array}$ & No specific provisions made & $N$ \\
\hline
\end{tabular}


national grid; no guidelines exist in the Grid Codes on costs for technical adaptation and/or costs-benefits of connection for new producers. With respect to the transportation segment the draft NREAP anticipates a 9.5\% biofuel penetration in Macedonia's fuel mix by 2020 . This again is highly dependent on both the EU directives (where biofuel blending targets have dropped by $30 \%$ in the past 6 years) and the REAP which is yet to be adopted.

In recent years advanced European economies such as Germany have seen resurgence in carbon energy technologies on the backdrop of the Eurozone crisis and growing resistance to nuclear power. Advanced Biofuels are the new renewable energy technology in the energy market. For these advanced biofuels to achieve commercialization, it is imperative for them to escape what the innovation literature depicts as, the 'Valley of Death' (Labelle and Goldthau, 2014). Miller et al. (2015) through a socio-energy systems lens point out that, without simultaneous conceptualization of the salient aspects of diverse social arrangements (or co-production), energy transitions will always run into socio-political resistance and controversies.

Along similar lines, public awareness and outreach although explicitly documented in the RED (Article 14), remain largely non-existent in the promotion of advanced biofuel projects in Macedonia (Table 1). In contrast, when one looks at Brazil and its success in implementing bio-ethanol projects, it is evident that socio-technical pressures coupled with government advocacy can allow biofuels to be nurtured and empowered in a protective niche through proactive legislations and strong political will (Sandalow, 2014; Smith and Raven, 2012).

Hence, this study, by documenting the uncertainties and gaps in the regulatory frameworks depicts that the benefits of niche protection and empowerment have not been extended to advanced biofuels in the EU vis-à-vis Brazil. Although scientific consensus on advanced biofuels as a renewable energy remains to be established, advanced biofuel production projects could help the EU transition away from a carbon economy and provides the time necessary to come up with better investment alternatives. Moreover, CEECs like Macedonia being transition economies themselves, offer an ideal platform for deployment of renewable energy projects.

\section{Conclusion}

While not acknowledging or favouring advanced biofuels as a renewable energy technology, this paper elucidates the obscurities in the current energy policies of the EU and its implications on potential and current stakeholders of, and investors in biofuels. Delving into energy policy literature, Wüstenhagen and Menichetti (2012) highlight the importance of risk perception in renewable energy investments; they suggest that investment is strongly influenced by the level of risk and uncertainty that accompanies an energy policy and that, policies that effectively reduce perceived risk for investors are more likely to result in large-scale deployment of renewable energy. This is more than exemplified in Macedonia where investment in advanced biofuel projects has been substantially affected by legislative vacillations. However, a competitive and well-functioning energy market will require substantial investment from the private sector in developing and expanding new energy technologies in conjunction with a clear and comprehensive policy framework.

Considering the above presented opinions of academia and civil society organizations, advanced biofuel projects seem to be in the midst of a complex energy system. Although the food versus fuel debate does not apply directly to these fuels, the use of land for the cultivation of cash crops brings up concerns of ILUC, intensive use of water and other agricultural resources, fertilizers and fossil fuels to operate equipment. This is the possibly the reason that biofuels are being questioned on their legitimacy in being called green or renewable.

The pace and form of green technology in Europe is dictated by the EU as a supranational regulatory authority and in turn, by its member states and their legislative environments. As shown by Smith and Raven (2012), at a certain point in the energy transition, it becomes imperative to adopt the correct narratives and policies to shape civil society perception and garner political support for RET proliferation. Similarly, for advanced biofuel projects, the challenge isn't in the commercialization of an unproven, new-to-market technology; the real test will be to see if the relevant stakeholders can shape the narratives adopted by the EU for its post-2020 phase of the RED and seek compliance to the current RED by the Government of Macedonia.

\section{References}

Action Aid (2012). Fuel for thought-Addressing the social impacts of EU biofuels policy, Brussels: ActionAid. https://doi.org/10.1163/2210-7975_HRD-0153-0067

Action Aid, BirdLife International, Climate Action Network Europe, CIDSE, Client Earth, ...\& World Rainforest Movent Urugay (2013). CEEweb network Publications. [Online]. Available from: http://www.ceeweb.org/ wp-content/uploads/2011/12/2013.06.17-CS-open-letter-to-MEPsSignatories.pdf [Accessed: 23 July 2016].

Action Aid, BirdLife International, Climate Action Network Europe, European Environmental Bureau, fern, Greenpeace, Oxfam, Transport \& Environment, Wetlands International, World Wildlife Fund. Pitfalls and potentials- The role of bioenergy in the EU climate and energy policy post 2020. [Online]. Available from: http://www.birdlife.org/sites/default/files/attachments/Bioenergy_post_2020_NGO\%20recs.pdf [Accessed: 23 July 2016]

Alcantara, C., Kuemmerle, T., Baumann, M., Bragina, E. V., Griffiths, P., Hostert, P., Knorn, J., Muller, D., Prishchepov, A.V., Schierhorn, F., Sieber, A., Radeloff, V. C. (2013). Mapping the extent of abandoned farmland in Central and Eastern Europe using MODIS time series satellite data. Environmental Research Letters. 8(3), pp.035035. https://doi.org/10.1088/1748-9326/8/3/035035

Atanasiu, B. (2010). The role of bioenergy in the National Renewable Energy Action Plans: a first identification of issues and uncertainties. London:IEEP. [Online]. Available from: http://www.ieep.eu/assets/753/ bioenergy_in_NREAPs.pdf 
Balat, M., Balat, H. (2009). Recent trends in global production and utilization of bio-ethanol fuel. Applied Energy. 86(11), pp. 2273-2282. https://doi.org/10.1016/j.apenergy.2009.03.015

Bauen, A., Berndes, G., Junginger, M., Londo, M., Vuille, F. (2009). Bioenergy: a sustainable and reliable energy source. A review of status and prospects. IEA Bioenergy: ExCo: 2009:06. Rotoura, New Zealand: International Energy Agency. [Online]. Available from: http://www. ieabioenergy.com/wp-content/uploads/2013/10/MAIN-REPORT-Bioenergy-a-sustainable-and-reliable-energy-source.-A-review-of-status-and-prospects.pdf [Accessed: 20 July 2016]

CEE Bankwatch Network. (2010, January 18). Letter to the EC on resource efficiency initiative. [Online]. Available from: http://bankwatch.org/ documents/letter_EC_ResourceEfficiencyInitiative_19Jan2011.pdf [Accessed: 23 July 2016].

Ćosić, B., Krajačić, G., Duić, N. (2012). A 100\% renewable energy system in the year 2050: The case of Macedonia. Energy. 48(1), pp. 80-87. https://doi.org/10.1016/j.energy.2012.06.078

Dedinec, A., Markovska, N., Taseska, V., Duic, N., Kanevce, G. (2013). Assessment of climate change mitigation potential of the Macedonian transport sector. Energy. 57, pp. 177-187. https://doi.org/10.1016/j.energy.2013.05.011

De Lucia, C., Bartlett, M. (2014). Implementing a biofuel economy in the EU: Lessons from the SUSTOIL project and future perspectives for next generation biofuels. Renewable and Sustainable Energy Reviews. 29, pp. 22-30. https://doi.org/10.1016/j.rser.2013.08.058

de Schutter, O. (2014). The transformative potential of the right to food, Human Rights Council, United Nations. [Online]. Available from: http:// www.srfood.org/images/stories/pdf/officialreports/20140310_finalreport_en.pdf [Accessed: 23 July 2016].

Di Lucia, L., Ahlgren, S., Ericsson, K. (2012). The dilemma of indirect landuse changes in EU biofuel policy-An empirical study of policy-making in the context of scientific uncertainty. Environmental Science \& Policy. 16, pp. 9-19. https://doi.org/10.1016/j.envsci.2011.11.004

Edwards, R., Mulligan, D., Marelli, L. (2010). Indirect land use change from increased biofuels demand. Comparison of models and results for marginal biofuels production from different feedstocks, Ispra: EC Joint Research Centre. https://doi.org/10.2788/54137

Eide, A. (2008). The Right to Food and the Impact of Liquid Biofuels (Agrofuels), Rome: FAO. [Online]. Available from: publish.uwo.ca/ dgrafton/ righttofood.pdf

Energy Agency of the Republic of Macedonia. (2015, March 22). Renewable Energy. Retrieved from Energy Agency of the Republic of Macedonia. Available from: http://www.ea.gov.mk/index.php?option=com_content \&view $=$ article\&id $=53 \&$ Itemid=\&lang=en [Accessed: 23 July 2016].

Energy Community. (2012a, October 18). Energy Community Ministerial Council adopts Renewable Energy 2020 targets. [Online]. Available from: https://www.energy-community.org/portal/page/portal/ ENC_HOME/NEWS/News_Details?p_new_id=6342 [Accessed: 13 September 2016].

Energy Community. (2012b, April 23). Energy Community Public consultation on the development of the Regional Energy Strategy of the Energy Community. [Online]. Available from: https://www.energy-community.org/ pls/portal/docs/1524178.PDF [Accessed: 23 July 2016].

Energy Community. (2016, September 12). Latest development: FYR of Macedonia Renewable Energy. [Online]. Available from: https://www. energy-community.org/portal/page/portal/ENC_HOME/AREAS_ OF_WORK/Implementation/FYR_Macedonia/Renewable_Energy [Accessed: 13 September 2016]
ePURE (2014). Statement from ePURE, the European renewable ethanol industry association. Following the European Energy Council, 13/06/2014. [Online]. Available from: http://ethanolproducer.com/ articles/11165/eu-reaches-an-agreement-on-iluc-caps-conventionalbiofuels-at-7 [Accessed 23 July 2016]

European Commission (EC). (2007). Communication to Council and Parliament 2007/COM(2006) 88 final/EC 10 January 2007 on Renewable Energy Road Map-Renewable energies in the 21st century: building a more sustainable future. [Online]. Available from: http://eur-lex.europa.eu/ legal-content/EN/TXT/PDF/?uri=CELEX:52006DC0848\& from=EN [Accessed: 23 July 2016]

European Commission (EC) Report from the Commission to the Council and the European Parliament 2010/COM(2010) 11 final/EC 25 February 2010 on Sustainability Requirements for the use of Solid and Gaseous Biomass sources in Electricity, Heating and Cooling. [Online]. Available from: http://eur-lex.europa.eu/legal-content/EN/TXT/PDF/?uri=C ELEX:52010DC0011\&from=EN [Accessed: 23 July 2016]

European Commission (EC) Study 2011/ IP/A/ENVI/ST/2010-15/EC February 2011 on Indirect Land Use Change and Biofuels. [Online]. Available from: http://www.europarl.europa.eu/RegData/etudes/etudes/join/2011/451495/ IPOL-JOIN_ET(2011)451495_EN.pdf [Accessed: 22 July 2016]

European Commission (EC). (2015). EU on track to meeting 20\% renewable energy target. [Online]. Available from: https://ec.europa.eu/energy/en/ news/eu-track-meeting-20-renewable-energy-target [Accessed: 13 September 2016]

European Commission (EC). (2016). Preparation of a sustainable bioenergy policy for the period after 2020. [Online]. Available from:https:// ec.europa.eu/energy/en/consultations/preparation-sustainable-bioenergy-policy-period-after-2020 [Accessed: 23 July 2016].

European Monitoring Centre on Change (EMCC). (2008). Trends and drivers of change in the European energy sector: Mapping report. Dublin: EMCC Eurofound. [Online]. Available from: https://www.eurofound.europa.eu/sites/default/files/ef_files/pubdocs/2008/12/en/1/ef0812en.pdf

European Union (EU). (1996). Directive 96/92/EC of the European Parliament and of the Council of 19 December 1996 on common rules for the internal market in electricity. [Online]. Available from: http://eur-lex.europa. eu/legal-content/EN/TXT/?uri=CELEX:31996L0092

European Union (EU). (2009). Directive 2009/28/EC of The European Parliament and The Council on the Promotion of the Use of Energy from Renewable Sources. [Online]. Available from: http://eur-lex.europa.eu/ Legal-Content/En/Txt/Html/?Uri=Celex:3200910028\&From=En $\quad[$ Accessed: 12 July 2016]

Eurostat (2016). Energy, transport and environment indicators-2015 edition. Brussles: European Union. [Online]. Available from: http://ec.europa. eu/eurostat/documents/3217494/7052812/KS-DK-15-001-EN-N.pdf [Accessed: 21 July 2016]

European Union (EU) (2016). Energy balance sheets 2014 data. Luxembourg: Publications Office of the European Union, 2016. https://doi.org/10.2785/795827

Faaij, A. P. (2006). Bio-energy in Europe: changing technology choices. Energy Policy. 34(3), pp. 322-342. https://doi.org/10.1016/j.enpol.2004.03.026

Fargione, J., Hill, J., Tilman, D., Polasky, S., Hawthorne, P. (2008). Land clearing and the biofuel carbon debt. Science. 319(5867), pp. 1235-1238. https://doi.org/10.1126/science.1152747

FIAN (2008). Agrofuels in Brazil - Report of the Fact-finding Mission on the impacts of public policies encouraging the production of agrofuels on the enjoyment of human rights to food, work and the environment among the peasant and indigenous communities and rural, Heidelberg, Germany: FIAN. [Online]. Available from: http://www.rtfn-watch.org/fileadmin/_ migrated/content_uploads/brazil_agrofuels.pdf [Accessed: 21 July 2016] 
Fischer, G., Prieler, S., van Velthuizen, H. (2005). Biomass potentials of miscanthus, willow and poplar: results and policy implications for Eastern Europe, Northern and Central Asia. Biomass and Bioenergy. 28(2), pp. 119-132. https://doi.org/10.1016/j.biombioe.2004.08.013

Georgiev, G. (2015). Albania, Bosnia, Macedonia to adopt national renewable energy action plans without delay - Energy Community. [Online]. Available from: http://renewables.seenews.com/news/albania-bosnia-macedonia-to-adopt-natl-renewable-energy-action-plans-without-delayenergy-community-465065\# [Accessed: 23 July 2016].

Gul, S., Yanni, S., Whalen, J. (2014). Lignin controls on soil ecosystem services: Implications for biotechnological advances in biofuel crops. In: F. Lu, ed. Lignin: Structural Analysis, Applications in Biomaterials and Ecological Significance. Hauppauge, NY, USA: Nova Science, pp. 375 416. [Online]. Available from: http://joann-whalen.research.mcgill.ca/ publications/Lignin $\% 20$ Chapter\%2014\%202014.pdf

Government of the Republic of Macedonia Ministry of Economy (2015). Renewable Energy Action Plan for The Republic of Macedonia until 2025 with vision until 2030, Skopje, Republic of Macedonia. [Online]. Available from: https://www.energy- community.org/portal/page/portal/ENC_ HOME/DOCS/3996377/2AEF1526B32439F9E053C92FA8C03714.pdf [Accessed: 13 September 2016]

Hammerschlag, R. (2006). Ethanol's return on investment: a survey of the literature 1990-present. Environmental Science and Technology. 40, pp. 1744-1750. https://doi.org/10.1021/es052024h

International Institute for Sustainable Development(IISD). (2013) Biofuels-At What Cost? A review of costs and benefits of EU biofuel policies. Canada: International institute for sustainable development. Available from: https:// www.iisd.org/gsi/sites/default/files/biofuels_subsidies_eu_review.pdf

IPA Energy and Water Consulting (IPA). (2010) Study on the Calculations of revised 2020 RES targets for the Energy Community. Study on the Implementation of the New EU Renewables Directive in the Energy Community. Edinburgh: IPA Energy + Water Economics. Available from: https://www.energy-community.org/portal/page/portal/ENC_HOME/ DOCS/2514179/0633975AADE97B9CE053C92FA8C06338.PDF

Knopf, B., Nahmmacher, P., Schmid, E. (2015) The European renewable energy target for 2030-An impact assessment of the electricity sector. Energy Policy. 85, pp. 50-60. https://doi.org/10.1016/j.enpol.2015.05.010

Kondili, E. M., Kaldellis, J. K. (2007). Biofuel implementation in East Europe: Current status and future prospects. Renewable and Sustainable Energy Reviews. 11(9), pp. 2137-2151. https://doi.org/10.1016/j.rser.2006.05.001

LaBelle, M., Goldthau, A. (2014). Escaping the valley of death? Comparing shale gas technology policy prospects to nuclear and solar in Europe. The Journal of World Energy Law \& Business. 7(2), pp. 93-111. https://doi.org/10.1093/jwelb/jwt020

Laborde, D. (2011). Assessing the land use change consequences of European biofuel policies. Washington: International food policy institute (IFPRI). Available from: http://trade.ec.europa.eu/doclib/docs/2011/october/tradoc_148289.pdf [Accessed: July 23 2016]

Levi-Faur, D. (2009). Regulatory capitalism and the reassertion of the public interest. Policy and Society. 27(3), pp. 181-191. https://doi.org/10.1016/j.polsoc.2008.10.002
Lewandowski, I., Weger, J., Van Hooijdonk, A., Havlickova, K., Van Dam, J., Faaij, A. (2006). The potential biomass for energy production in the Czech Republic. Biomass and Bioenergy. 30(5), pp. 405-421. https://doi.org/10.1016/j.biombioe.2005.11.020

Markovska, N., Taseska, V., Pop-Jordanov, J. (2009). SWOT analyses of the national energy sector for sustainable energy development. Energy. 34(6), pp. 752-756. https://doi.org/10.1016/j.energy.2009.02.006

Oxfam International (2008). Another Inconvenient Truth- How biofuel policies are accelerating climate, Briefing Paper, Oxford, UK: Oxfam. [Online] Available from: http://www.oxfam.org.hk/content/98/ content_3535tc.pdf [Accessed: 23 July 2016].

Ruble, I. (2015). EU Energy Security Through Supply Diversification: Do Natural Gas Reserves in the Eastern Mediterranean Present A Viable Option?. IAEE Energy Forum, International Association for Energy Economics. [Online]. Available from: https://iaee.org/en/publications/ newsletterdl.aspx?id=265 [Accessed: 13 September 2016]

Sandalow, D. B. (2006). Ethanol: Lessons from Brazil. The Brookings Institution. Available from: http://www.brookings.edu/research/articles/2006/05/energy-sandalow [Accessed: 23 July 2016].

Scarlat, N., Dallemand, J. F., Monforti-Ferrario, F., Banja, M., Motola, V. (2015). Renewable energy policy framework and bioenergy contribution in the European Union-An overview from National Renewable Energy Action Plans and Progress Reports. Renewable and Sustainable Energy Reviews. 51, pp. 969-985. https://doi.org/10.1016/j.rser.2015.06.062

Smith, A., Raven, R. (2012). What is protective space? Reconsidering niches in transitions to sustainability. Research Policy. 41(6), pp. 1025-1036. https://doi.org/10.1016/j.respol.2011.12.012

Solomon, B. D. (2009) Biofuels and sustainability. Annals of the New York Academy of Sciences. 1185, pp. 119-134.

https://doi.org/10.1111/j.1749-6632.2009.05279.x

The World Bank. (2016). Macedonia, FYR Energy imports, net (\% of energy use) 2010-2014. WITS, World Bank. [Online]. Available from: http:// data.worldbank.org/indicator/EG.IMP.CONS.ZS?locations $=$ MK [Accessed: 13 September 2016]

Transport and environment (TE), BirdLife International (BL), European Environmental Bureau (EEB). (2014). Proposal to address Indirect Land-Use Change (ILUC)- Position Paper. [Online]. Available from: http://www.eeb.org/?LinkServID=786E652D-5056-B741DB5702236B13B9B1\&showMeta=0\&aa [Accessed: 23 July 2016].

van Dam, J., Faaij, A. P. C., Lewandowski, I., Fischer, G. (2007). Biomass production potentials in Central and Eastern Europe under different scenarios. Biomass and Bioenergy. 31(6), pp. 345-366.

https://doi.org/10.1016/j.biombioe.2006.10.001

Vapo (2014). Vapo Oy freezes the Kemi biodiesel project. Press Release Feb 21. [Online]. Available from: http://www.vapo.fi/en/media/ news/1997/vapo_oy_freezes_the_kemi_biodiesel_project [Accessed: 23 July 2016].

Wüstenhagen, R., Menichetti, E. (2012). Strategic choices for renewable energy investment: Conceptual framework and opportunities for further research. Energy Policy. 40, pp. 1-10. https://doi.org/10.1016/j.enpol.2011.06.050 